\title{
Christian Sexual Ethics in a Time of HIV/AIDS - A Challenge for Public Theology ${ }^{1}$
}

\author{
Michael Haspel \\ (University of Marburg)
}

\section{ABSTRACT
Christian Sexual Ethics in a Time of HIV/AIDS - A Challenge for Public Theology

HIV/AIDS poses an enormous challenge for the Christian church in Africa. Though many congregations engage in practical social programmes addressing the medical and social problems related to HIV/AIDS often there is no adequate theological concept dealing with HIVIAIDS. This article argues that starting from biblical insights and Christian anthropology in the current situation a contextual theology adressing HIV/AIDS and a respective sexual ethics have to be developped which enables Christians to live responsibly in a time of HIVIAIDS without demonising sexuality. This, in turn, could contribute to the ethical discourse in civil society and thus foster the development of a public theology.

\section{INTRODUCTION}

Talking about Christian sexual ethics is probably provoking very different reactions from several sides. On the one hand, the endeavour is seen as burdened with a long history of oppression and devaluation of sexuality in Christianity. Against this background, some would say that Christian ethics ${ }^{2}$, due to its tradition of Puritan sexual morality, does not have the faculty to address this problem

1 This article is based on lectures presented at a conference of the WCC, at the Chancellor College of the University of Malawi, at the University of Stellenbosch, at the University of Kwa-Zulu Natal, Pietermaritzburg and at the University of Pretoria. The author is grateful for the invitations and the valuable contributions in the discussions. As visiting research scholar the author presented this paper on $24^{\text {th }}$ March 2004 at the University of Pretoria.

2 Although the concept of Christian ethics in this paper will be developed from a Protestant perspective, the more universal notion of "Christian" will be used to indicate that the intention is not to develop merely a denominational view. 
adequately in times of rapid social change and increasing new challenges, especially for the youth.

On the other hand, people might expect from theology and the church in what they perceive as times of rapid decline of moral behaviour, clear guidelines supposedly based on clear scriptural evidence condemning all the negative phenomena they attribute to the "Western" lifestyle, which is seen as advocating promiscuous conduct and free sexual relations. Even though these two perspectives are quite different, in both cases the church and theology are obviously not seen as being capable of developing ethical orientation for people, who constructively have or want to be involved in finding their ways in a process of ongoing social change.

But this is indeed what Christian ethics is about. It shall provide orientation based on the specific understanding of and perspective on the world we are living in, which in the perspective of Christian faith is founded in the Gospel message. And the sphere of sexuality is probably a major test case whether Christian theology is able to live up to the task to help people with orienting themselves in the world they live in based on the understandings of the human being and the world that follow from the perspective of faith. It is a special test case, given that when it comes to sexuality, every one is involved in an extremely personal way. Sexuality is very intimate. It is very serious. It always has been and it definitely is in the time of HIV/AIDS. Sexuality has much to do with who we are or at least who we think we are. And it is well-known that issues of identity bring a special momentum with them. Thus, Christian sexual ethics is challenged to make a meaningful contribution in an area where people are affected at the very core of their self-understanding and existence. Since it is so personal, this field also qualifies to be exemplary for the concept of Christian ethics: the personal sphere has to be related with the social and cultural context. How can Christian ethical principles be applied in different and changing social contexts? Therefore, even in the field concerning sexuality, it becomes paramount not only to address the personal implications, but also the social structures.

Furthermore the question arises from where the guidelines are derived. Especially in the field of ethics one can encounter the phenomenon, that specific biblical verses are taken literally and used to justify certain positions. Though few people would accept that taking interest on money is against scriptural evidence, others would 
be more willing to assume that there is normatively binding evidence in scripture ruling out for example homosexuality or premarital sex (though scriptural evidence on the first is rather debated and more or less lacking on the latter). Therefore, if Christian sexual ethics is addressed, the methodology has to be clarified.

First, a brief analysis of the anthropological foundation of a theological understanding of sexuality will be given (I.), which is to be followed by a reconstruction of the guiding models biblical tradition provides with regard to the way human beings live together as couples and families (II.). We proceed by addressing current insights of social anthropology with regard to sexuality (III.). Then we have paved the ground to address the issues of sexual ethics proper (IV.). Though issues of HIV/AIDS are already addressed in the former section, concluding remarks will be made regarding some ethical and systematic-theological issues related to HIV/AIDS (V.).

\section{SEXUALITY IN THE PERSPECTIVE OF CHRISTIAN ANTHROPOLOGY ${ }^{3}$}

For a long time, Christian anthropology was influenced by the reception of the Hellenistic dualism of body vs. soul or body vs. spirit. Through Augustine this dualistic, even dichotomic division of body and soul, of physical and spiritual was explicitly connected with a negative concept of sexuality, which he attributed to the lower, physical functions of human existence. Augustine perceived sexuality as an evil and as an expression of sin. Only the very sexual act within marriage, which was performed with the intention of procreation, was seen as legitimate. Even that act was not seen free of sin, as Augustine saw original sin (peccatum originale originans) passed on through it to the infant to be, who therefore is marked by sin from the very moment of his or her birth on (peccatum originale originatum). From this perspective the goal of human longing only could be to master sexual desire and finally to overcome the physical demands of the body. For Augustine sexual desire (concupiscentia) was the prototype of actual $\sin ^{4}$. By this sexualisation of $\sin$ he

3 Cf Haspel (2004).

4 One has however to do justice to Augustine by adding that he developed this notion of sexuality against the background of a Hellenistic culture, in which the longing for sexual lust accompanied by widespread promiscuity was culturally endorsed, which he found rather disgusting. So 
triggered a long history of devaluation of sexuality as well as a narrow understanding of sin. Sexuality was perceived negatively, as danger, as sinful and was connected with femininity (Hartlieb 1997:155-174; Hartlieb 2000:99-121). In turn, sin was mainly perceived as personal misbehaviour in the sexual realm, which not only has implications for theological ethics but also for dogmatics, since the pervasive nature of the power of sin and its existential as well as societal consequences might easily be overlooked by focussing on the personal intimate sphere (1 Cor 6:12-20).

However, during the last century, New Testament studies have rediscovered that the anthropological assumption of Augustine is not supported by biblical evidence. Though Paul is also using dualistic language by distinguishing "flesh (sarx)" and "spirit (pneuma)" it is not a dichotomic understanding of the human body (Cf Gl 5). The human being is seen holistically as somatic existence. The Greek word soma comprises all of the faculties of the human being (physical, spiritual, intellectual). However, the soma will either be under the influence of the "flesh" -or as some bible translations put it: sinful nature- or alternatively under the influence of the Spirit. This applies to all endeavours of human existence. We either do them according to the sinful nature (kata sarka) or according to the Spirit (kata pneuma) (Kaesemann 1969[1993]: 9-60). If we apply that to sexuality we can conclude, that sexuality is not per se good or bad; it depends whether sexuality is lived kata sarka or kata pneuma. In other words: sexuality is a good gift of God, part of his/her good creation and is -as the entire creation- in danger of the corruption of sin. Thus sexuality stands under the principal ethical guideline, which for Paul and other biblical authors is the epitome of Christian ethics: to love one's neighbour (Gl 5:13f.). Whether sexuality is lived kata pneuma is then dependent on the social relations, in which people live: First of all the relations with the immediate partner, but also the relations within family and larger community. As these relations do differ culturally and also throughout a lifetime it might be that sexual ethics in a Christian perspective turn out to be contextual with regard to these aspects. In the next section there is an analysis of the way social relations,

his own position might be understood as overreacting against his environment. 
together with the aspect of sexuality, can be lived out with responsibility through the biblical tradition.

\section{PERSONAL RELATIONSHIP AND INSTITUTION. MARRIAGE, FAMILY AND LIFE-FORMS IN BIBLICAL PERSPECTIVE}

The biblical authors presuppose the existence of institutions such as marriage and family. Therefore these are not founded explicitly in Scripture as exclusive or absolute life forms. In the reports of creation it is narrated that male and female are in a special relation (Gn 1:27), but a specific institutionalised form of marriage is not deducted. Actually, in the Hebrew Old Testament there isn't even a proper word for marriage. In the texts of the Old Testament polygamy is seen as an acceptable life form. The protection of the institution of marriage as safeguard for the family in the sixth commandment and corresponding texts has to be seen against the background of social history. The social and juridical position of the wife as well as of all family members (the elderly, children, younger siblings) had to be secured, since they all depended on the formal marriage and family relations for their living.

Frequently in the Old Testament texts we find that the covenant of God with his/her people is portrayed in the image of marriage (Is 54; Hs 2; Ezk 16). This metaphor of marriage is also included in the New Testament and transferred to the relationship of Christ and the Christian congregation (Rev 21; Eph 5). God's persevering faithfulness to his/her covenant with his/her chosen people thus can be seen as model for the covenant of marriage, which in turn might be understood in analogy to the covenant of peace and salvation ${ }^{5}$.

The Old Testament tradition is received in a complex way in the New Testament. Some views are confirmed, others not; partially they are relativised, partially they become radicalised. A radicalising interpretation is to be found in the antitheses of the Sermon on the Mount, where Jesus reiterates Old Testament teachings and

\footnotetext{
5 However one has to keep in mind, that the marriage analogy is drawing on the metaphor of the unfaithful bride, which in turn triggered a long and influential anti-judaistic iconographic tradition. Also the relationship of Jahwe to his bride is sometimes pictured as violent (Cf. Baumann 2000).
} 
interprets them in a radical way. For example, the practice of divorce by issuing a divorce certificate accepted in Judaism of his time, is criticised in the Sermon on the Mount but also in other texts, because Jesus objects against a mere formal fulfilment of the commandments (Mt 5: 31f; Mk 10: 1-12). Especially in Mk 10: 1-12, where a word of Jesus recurs on both accounts of creation (Gn 1:27;2:24) and emphasises the bodily unity in the relationship of man and woman, we can see that it is the personal unity and holistic life-partnership, which is at the centre of sex and family relations. With this emphasis on the aspect of personal relationship comes the relativisation of the formal, institutional aspects of the family. In Mk 12: 25, marriage is seen as something timely and preliminary: Jesus answers the Sadducees' question, which marriage of a woman who had been widowed and remarried seven times (cf. Dt 25: 5-10) would be valid after resurrection, by pointing out that the institution of marriage will be dissolved in the eschaton. Though, this is not to be understood as the abolition of the institutional aspect of marriage, but as its qualification according to its very function to provide a framework for a durable personal relationship of a man and a woman, in which God's love can be experienced and in turn passed on. The documents of Pauline theology also do not contain an elaborated doctrine of marriage. In Paul's writings the complementation of the institution of marriage by the possibility of celibacy is found. This is in sharp contrast to the mainstream of Judaism, where marriage was seen as a religious and ethical duty. For Paul celibacy was not only a possibility, he even declared it a Christian charisma (1 Cor 7: 7). But marriage for him remains a strong "second option".

In addition there are many examples in the New Testament, where family structures are transcended: The disciples upon their calling leave their families and their work. This in turn means they might endanger the material support of the family, the provision of which normally depends on the young men (cf. inter alia Mk 1: 16ff; 2: 14). Biological family ties are called into question according to Jesus' transmitted kerygma. He relativises the relationship with his own mother (Mt 12:48; Mk 3:31-35); the concept of "father" he only wants to be applied to the "heavenly father" (Mt 23:9). This transgression of traditional family structures culminates in his demand, that one should love Christ more than one's parents respectively children, the relation with God is more important than familial bonds (Mt 10:37). 
This transgression of biological relations is in continuity with the relativisation of ethnic boundaries of the ethos in the Old Testament. The opening up of the family ethos by Jesus subjugates all concrete commandments under the comprehensive and universal double commandment of love. The two commandments of the Old Testament to love God and to love one's neighbour are combined by the synoptics and interpreted as the fulfilment of the Law (Mk 12:28-34; Mt 22:34-40; Lk 10:25-28; cf. Dt 6:5; Lv 19:18). In his letter to the Romans, Paul explicitly correlates the single commandments and the commandment of love: "Let no debt remain outstanding, except the continuing debt to love one another, for she/he who loves her/his fellow human has fulfilled the law. The commandments 'Do not commit adultery', 'Do not murder', 'Do not steal', 'Do not covet', and whatever other commandments there may be, are summed up in this one rule: 'Love your neighbour as yourself'. Love does no harm to its neighbour. Therefore love is the fulfilment of the law" (Cf Rm 13:8f, Kaesemann 1980:347-351).

The commandments of the Torah are thus correlated with the double commandment of love. The commandment of love becomes (for Christians) the qualitative criterion and the hermeneutical key for the interpretation of Old Testament norms. The foundation of New Testament ethics transcends the old covenant and puts God's justification through Christ in the centre. When in faith justification is experienced as grace and liberation, Christian life in love emanates. This is the meaning of Christian freedom, which is realised in love: "You, my brothers and sisters, were called to be free. But do not use your freedom to indulge the sinful nature; rather, serve one another in love" (G1 5: 13).

For our context it is important to note, that family relations and specific forms of institutionalised life forms are partially relativised and strictly seen in analogy to the correlation of the relationship with God and love of one's neighbour. From this it follows that in ethical perspective it can be formulated: Through the accounts of creation and justification in the Christian tradition all human beings are seen as the images of God and as children of God with equal dignity. This is grounded in the relationship with God and has to be realized in acting love. Thus, the ethical principles for the evaluation of marriage, family and other life forms have to be strongly oriented at the commandment of love. Important is the quality of the respective relationships, institutional forms, though being important, have to be 
judged and designed accordingly (Schrage 1989:45-105, 229-238; Keil 1997:14-29; Haspel 1998:33-43).

This concurs with the Protestant understanding of marriage, which is not seen as a sacrament, but - though installed by God seen as a worldly institution. Therefore the habits of wedding and the legal regulations of marriage may differ in different regions from each other (Luther 1529). For the issue of Christian sexual ethics it follows that the mere form of an institution cannot be the decisive criterion. Theologically speaking, the so-called ethics of the orders of creation is not only too static to cope with social change (even from a strictly theological point of view). However, it is also neither biblically justified nor hermeneutically adequate. In a soteriological perspective the so-called orders of creation and individual commandments always have to be correlated with the double commandment of love ${ }^{6}$.

This provides the capability to perceive social change and to be able to provide orientation in it from a theological-ethical perspective. It can be illustrated with two examples: In most European societies the institution of marriage underwent significant change in recent decades. Though there are severe changes, most people still value partnership and marriage very highly. But, for example, the age when people get married increased significantly. The main reason is that education requires more time and many people don't start having their own sufficient income before they are in their late twenties or even thirties. By this token one can argue that the institution of marriage was fundamentally transformed. For many it is no longer the beginning of an intimate relationship but rather takes place at the time when a couple, which often has lived together for some time, decides to have children and build a family (Nave-Herz 1997) ${ }^{7}$. This has significant implications also for

6 Bonhoeffer already realised that the traditional Lutheran ethics of orders of creation was not capable of dealing with societal change and social transformation. He thus developed the concept of mandates, which are less static and more capable of contextualisation in different situations. (cf. Botman 2002:97-104)

7 For the most recent statistics in Germany see Bundesministerium für Familie, Senioren, Frauen und Jugend (ed.): Die Familie im Spiegel der amtlichen Statistik. Lebensformen, Familienstrukturen, wirtschaftliche 
wedding services and counselling. For the field of sexual ethics one could argue that given this change in the institution of marriage, one should not per se condemn people living together unmarried. The question is rather whether they live together responsibly. The same can be applied to the situation in more traditional social settings. If there are certain expectations of parents in law the bridegroom has to meet before he is allowed to marry their daughter (lobola) that might be delaying marriages also. Especially if young men are engaged in tertiary education or are without a job, this might lead to a situation where they actually live in a permanent relationship with a woman, even have children, but are inhibited of getting married (Denis 2003:63-77) ${ }^{8}$.

The argument so far tried to show, that for formulating ethical criteria for sexual matters one has to take into account the Christian concept of anthropology as a point of departure (anthropological presupposition). Furthermore it was argued, that we are not likely to find orientation solely by looking at the institutions of marriage and family, since they themselves are viewed in the biblical tradition as subject to change and development (socio-historic presupposition). As guiding principle we identified the double commandment of love (ethical presupposition) with which the individual commandments have to be correlated hermeneutically (hermeneutical presupposition). In order to spell out principles of ethical orientation in the field of sexuality more concretely, the questions of how sexuality can be adequately conceived have to be considered. In the next section it is attempted to outline four important features of sexuality in the current social and cultural context by employing the findings of social anthropology against the background of Christian anthropology.

Situation der Familien und familiendemographische Entwicklung in Deutschland, Berlin, new expanded ed. 2003.

8 Very different yet in the result similar problems are posed by the system of migrant labour, through which for many people it is structurally impossible keeping up the institution of marriage and family (Cf. Moodie \& Ndatshe 1994). 


\section{SEXUALITY. INSIGHTS FROM SOCIAL ANTHROPO- LOGY ${ }^{9}$}

As basic anthropological phenomenon sexuality takes manifold shapes. It varies culturally, biographically and with regard to gender. This makes unambiguous definition and fixation difficult. While biological models mainly emphasize the natural determination of sexual instincts and conclude that there is something like a natural order of sexual relations, socio-cultural models stress that sexual motivation and behaviour patterns are to a large extent culturally mediated and in turn learnable and alterable. Thus a concept seems to be adequate which perceives sexuality as a dialectical relation of biological prerequisites, like sexual impulse (libido) and the respective cultural shape as well as the individual (gendered) appropriation. This corresponds with the differentiation of 'sex' (biological) and 'gender' (socio-cultural).

As constitutive element of human existence sexuality comprises several forms of expression and meaning. There can be identified (at least) four aspects: The aspect of identity refers to the possibility that sexuality provides the experience of self-determined bodily individual identity, comprising the experience of bodilyspiritual wholeness. This is in turn a subjective prerequisite for the capacity, to respect the integrity of others and to get into relation with them.

The aspect of relationship lends expression to the experiences of intimacy, warmth, trust and safety, which can be made in sexual relations. This is strongly connected with the desire to establish permanent and reliable relationships.

The aspect of pleasure comprises the bodily and spiritual experiences of pleasure in sexuality, including passion and ecstatic experiences, which are expressions and sources of vitality.

From this it follows the vitalising power of sexuality, which can be expressed with the aspect of fertility/creativity. The first thought might be about procreation, but this aspect includes more: with regard to the relationship, to the social relations and personal development sexuality can contribute to creativity and vitality. 
The four aspects are all dynamically interrelated. The emphasis on the different aspects may vary according to the biographical phase, socio-cultural context and individual appropriation. In the period of youth other aspects may be important than let's say in the family period of one's life. With regard to a successful socialisation and satisfying sexuality it is necessary that all four aspects are kept interrelated and in a certain balance. The separation of one of the aspects may become problematic or even pathological (Sielert 1993).

\section{PRINCIPLES OF CHRISTIAN SEXUAL ETHICS}

The following reflections on a Christian sexual ethics are based on this concept of sexuality, which in turn is founded in the anthropological foundations as explicated above.

Sexual ethics has to be distinguished from sexual morality. The latter gives account of the norms, which are factually valid or discursively demanded in a certain society at a certain time. Sexual ethics, however, is understood as the reflection on sexual morality, sexual behaviour and societal structures of lived sexuality. With regard to sexual morality sexual ethics can assume the function of foundation as well as critique. With regard to sexual behaviour sexual ethics will ask about normative problems and will try to provide orientation in terms of ethical principles or maxims. With regard to the societal dimension it is necessary to analyse social and historical dependencies as well as to critically illuminate respectively alter societal institutions, which influence (individual) sexuality.

Christian sexual ethics has its foundation and motivation in the contemporary concept of theological anthropology. The witnesses of Scripture are thus important sources and orientation. However, as we have seen, individual verses must not be taken out of their context, but they have to be interpreted in the context of Scripture as a whole. For sexual ethics the dialogue with human and social sciences is imperative.

For Christian sexual ethics the theological elaboration of the biblical narrative of the creation of the human being as female and male in the image of God (Gn 1:27) is foundational. Here two important features is encountered: All human beings are endowed with equal dignity and the human nature has to be understood holistically as somatic existence. Contemporary interpretation of the Pauline doctrine of justification is incorporating this insight and 
renews that individual recognition before God is not dependent on human merit. But in the acceptance of one's own limits -speaking traditionally: by grace- the freedom opens up to overcome these very limits. The justification of the sinners opens the door for the responsible formation of one's own life and in turn refers to the fact that with one's own recognition by God by the same token the recognition of all human beings is performed. The individual relationship with God constitutes from the very beginning the social relations with our fellow human beings. These social relations shall be realised according to the commandment of love, which in turn is aimed at justice (Haspel 2003:472-490; Bloomquist et al 2003:171186).

These insights are foundational for a Christian understanding of relations between the sexes, since the constitutive difference of the sexes is oriented towards their fundamental equality (e.g. Gl $3: 28)$.

Pursuant to societal modernisation/globalisation the structural presuppositions of gender roles are transformed, especially for women, but also with regard to family structures. The women's liberation movement addressed discrimination, because of gender, and fostered emancipation. This in turn contributed to calling into question traditional repressive sexual morality, which was also robbed of its socio-structural foundation and function (Dube 2003:71-93). Through the increasing gap between (early) sexual maturity and (late) social maturity in addition with the availability of reliable contraceptives (such as the "anti-baby-pill") since the early sixties traditional sexual morality became increasingly under pressure. With the new opportunities there arises new freedom but also new problems.

Though we know that concrete moral and ethical sexual norms are relative to their respective context, it is far from obsolete trying to gain ethical orientation for the conduct in sexual relationships and with regard to cultural and societal arrangements regarding sexuality. To the contrary, the praiseworthy opening up of new freedom for individual biographical designs and forms of personally chosen sexuality is in need of reflection on sexual ethics and the offer of ethical principles, which help to orient oneself responsibly and act accordingly (De Villiers 2003:23-38). 
If one takes the fundamental orientations of Christian anthropology and sexual ethics mentioned above and relates them with the four aspects of sexuality we have elaborated on, the following principles for a Christian sexual ethics can be concluded:

If we look at the aspect of identity from a normative perspective the first positive principle, which follows is selfdetermination and negatively this entails the avoidance of physical and psychological violence, which in turn can be formulated as principle of non-violence. This is evident with regard to explicit physical violence such as rape (including forced sex in relations and marriage), child abuse, clitoridectomy and other violations of physical integrity, which in many countries are also sanctioned by the codes of criminal law (LenkaBula 2002:55-68). Furthermore, the principle of non-violence includes the mutual responsibility to avoid infection with sexually transmitted diseases (STD), especially HIV/AIDS. In the perspective of the principle of non-violence also structural forms of violence have to be addressed, especially sexist and patriarchical structures, which still dominate gender relations and result in inequality, asymmetry and dependence.

With the aspect of relationship the principles of voluntariness and equality become paramount. They require that mutual needs and expectations are made transparent. Transcending the individual constellations, these principles also urge to uncover and resolve societal and psychological causes of dependency and inequality. From this it follows that gender and relationship roles need to be designed more flexible in order to allow for a broader pluralisation of life-forms. The goal of the individual biographical development of sexuality is its personal integration. Thus love, permanence and trust are most important principles of sexual ethics, which foster the development of life-long relationships.

With the aspect of pleasure, manifold ethical problems come to the fore. First of all, the separation of pleasure and the alienation of sexuality in the bourgeois-capitalist system, which offend against the principle of self-determination. The commercialisation of sexuality, the transferral of categories of consumerism and achievement driven society into the sexual realm are to be objected to according to the principles developed here. Prostitution and pornography are but the most outrageous forms of a comprehensive pervasiveness of media and advertisement with commercialised stereotypes of sexuality. The impact of which is only increased by the omnipresence of the new 
media. These increasingly alienated portrayals of sexuality do not only result in the heteronomy of guiding concepts in sexual affairs, but also in latent sexual violence against women, who are pictured stereotypically (Qakisa 2002:79-92). As a consequence of this increasing sexualisation of the public sphere through media and advertisement it is also observed that a de-erotisation of the private sphere takes place.

These sexist structures are re-enforced by the over-imposition with political and economic dependencies in a world system structured according to the difference between metropoles and the periphery. Due to the massive inequality between the North-Western and the Southern hemisphere and its structural reproduction within individual states sexist, often combined with racist exploitation and violence are sustained. Sex tourism, enforced prostitution, exploitative arranged marriages with disadvantaged women are but the most significant features of it. Christian sexual ethical reflection has thus to address and critique the current capitalist world system and finally aim on its reform.

If the aspect of creativity/fertility of sexuality is addressed, we also encounter certain normative implications. In terms of reproduction special responsibility is required by (heterosexual) partners with regard to birth control respectively birth planning. The decision for and the responsible performance of contraception as well as the decision of having a child is within the responsibility of both partners and needs to be achieved transparently and consensually.

If the dimension of fertility/creativity is not narrowly identified with reproduction, sexuality, which is not aiming on reproduction should not be seen as less valuable. [If this is not arbitrarily confined to heterosexual relationships, it has consequences for the evaluation of homosexual relationships as well. If homosexual relationships fulfil the normative principles which are developed here, there seems to be no reason, why they should not be accepted on the same ground as heterosexual relationships, which comply with these principles] (Kiel et al 2000).

The principles of Christian sexual ethics developed here are no concrete rules of conduct, which attempt to casuistically evaluate individual behaviour and sexual practices (though they imply consequences for this). They rather have the status of principles, 
which are to be concretised respectively. Though they do claim to have normative validity in the framework of the given foundation, they differ, however, with regard to the universality of their validity claims: While the principle of non-violence is pointed categorically against any form of destructive violence, other norms depend on the constellations and situations they are applied to. As general principles (Huber 1993:573-592) they have to be applied according to differing situations concretely and individually (De Villiers 2003:34). This requires a lot from the people affected. They have to take responsibility for themselves and mutually. This requires selfdiscipline and the ability to accept one's own limits. Thus, social support is necessary, which makes sex information, education and counselling imperative for churches and other societal institutions. Even though it has been shown that principles of sexual ethics are relative to changing contexts, they are not arbitrary! (Kiel 1966:6778). In the responsible personal and communicative application the ethical orientation in freedom becomes committing.

\section{THE CHALLENGE OF AIDS: SEXUAL ETHICS BETWEEN LIBERATION AND RESTORATION ${ }^{10}$}

From what has been said so far, there are direct consequences, if there are attempts to apply the principles to some issues related with the spread of HIV/AIDS. For example, the principle of non-violence and the paramount reality of rape in South(ern) Africa; or the principle of equality and the traditional patriarchy as well as the new (socio-economic) domination of young men over women that inhibit the self-determination of women with regard to her own sexuality, especially when it comes to forced sex and high-risk sexual practices (Denis 2003:70; Haddad 2002:93-116). Furthermore what was said in general about the socio-economic structures applies all too well to the problem of HIV/AIDS. Nevertheless, in this section it will be attempted to explore how we can interpret theologically HIV/AIDS more fully and what consequences can be drawn in the perspective of a Christian sexual ethics.

When HIV/AIDS started to be recognised publicly in the 1980s many Christian churches reacted with a theological interpretation that saw HIV/AIDS as the punishment of God for individual sins (in

10 Cf. Haspel (2003:510-514). 
the sense of wrongdoing). Since originally it were predominantly men which were infected, and sexual intercourse could be assumed as the venue of infection, this interpretation seemed to have a certain plausibility for some (Mwaungulu et al 2001:4f; Nicolson 1996:2638; West 2003:335-344).

However it is based on a questionable theological tradition often referring to Romans 1:18-32, which identifies the concept of sin with actual sin in the sense of wrongdoing, which then in turn is sanctioned by a judging God. In African churches this position was not the least therefore influential, because it is compatible with the traditional dynamistic world-view in Southern and Eastern Africa. The disease could be interpreted as caused by spiritual powers or even witchcraft (Benn 2002:3-18; Weinreich et al 2003:128-133).

However, this misinterpretation could not be held up after HIV/AIDS was hitting women and children. Most of the infected were no longer identifiable as perpetrators and sinners, but many were infected by their own husbands or by certain rituals. Children were born already carrying the virus acquired from their own mothers during pregnancy. Meanwhile the majority of the infected are female. The proportion of children is increasing. Though prostitution and sexual violence play a prominent role in the spread of the disease, it is many women who are infected in their marital or pre-marital relationship by their own partner to whom they have been faithful (Moyo 1998:94-110; Ackermann 2002; Chauke 2003:128-148).

In accordance with John 9: 1-3, the narrative of the blind born man, whom Jesus healed on the Sabbath, individual sickness could no longer be generally understood as punishment for individual sins (ORK 1997:45-51; Benn 1997:179-193). Also HIV/AIDS no longer can be marginalized as a problem of some outcasts. The infection is eating its way right in the centre of the church. Drawing on the metaphor that the church is but the body of Christ on could say: the church has HIV/AIDS (Kanyoro 2001:2-5)!

However, it seems that theological reflection on the nature of HIV/AIDS and the churches' teaching about sexual ethics are not always consistent with what they actually do as social work addressing the HIV/AIDS problem. It probably is not an exception that in one and the same church service, there would be given time and attention to HIV/AIDS witness and to reports from various 
church groups doing important community work for those infected and affected by HIV/AIDS, and the sermon then would actually counteract these endeavours by repeating a rather traditional sexual morality, which is not at all contextual to the situation, let's say of the youth in a township in a metropolitan area (Nuernberger 2002:422-436). Consider the quote of Gerald West (2003:336): "Going to church for many young people who are HIV-positive means being preached at and preached against". What is rather needed is a theology and practise of the church that are consistent. And the reformulation of Christian sexual ethics is an important part of it. Thus, it is not only imperative to further develop the programmes and services the churches provide related to HIV/AIDS but also to develop a theology and a Christian sexual ethics which are not merely adjusting to the situation but by means of serious contextualisation are able to communicate the gospel in the given context in a meaningful way.

Certainly, promiscuity, prostitution and sexual violence all contribute to the frantic spread of HIV/AIDS. But it would be a shortcoming to conclude from this that the only legitimate Christian position is to brand all pre-marital sex as immoral and to leave it at that. This would be not totally wrong since abstinence and a monogamous way of life (being faithful) do reduce the risk of infection. But this not necessarily guarantees that it provides for an adequate understanding of sexuality, which empowered responsible behaviour (including the use of condoms, which not only protect against STD, but also help avoiding (teenage) pregnancies) and sexual experiences free of anxiety especially for youth. In addition it is questionable, if this position over all does really contribute to the reduction of infection (Carmody 2003:79-90) ${ }^{11}$.

The church and theology are challenged to provide for ethical orientation in sexual matters, which allows for the acceptance of sexuality as a good gift from God as well as engenders responsible sexual behaviour (ORK 1997:51-55). The most fundamental presupposition therefore is that this aspect of human existence is not treated as taboo. Many obstacles have to be overcome in this regard. On the one hand, sexuality is in many (African) cultures an issue,

11 Recent research in Zambia found that though youth affiliated with certain Christian churches do judge premarital sex as wrong, a majority of them nevertheless engage in it. 
which traditionally is not discussed publicly, especially not across gender lines (Hendriks 2002:362-372). Actually, often churches contribute to the enforcement of this taboo, by propagating traditional Christian sexual morality, which makes people experiencing sexuality as something threatening and stigmatises any forms of sexual experiences other than in marriage aiming on procreation. On the other hand, the sphere of sexuality is kept under a veil since in it the unjustified disparity of power between men and women and the exploitation of women is manifested paradigmatically. Any questioning of this power constellation might erode the traditional arrangement between sexes in which down to the bottom line wives too often do not have power over their own body (Nicolson 1996:100-152). Here it has to be realised that enculturalisation and indigenisation of Christianity not always rendered positive results. The super-imposition of traditional African patriarchy by the Christian version of it resulted in a permanent unChristian oppression of women and static hierarchical structures in many churches: "[T]he patriarchical structures of African culture are reinforced by the patriarchy of the Bible"(Phiri 2002:19-30; Chauke 2003:129-136).

The spirit of capitalism, originally introduced in Africa in the wake of Christian mission, turns itself now equally against traditional African culture as well as against the ethics of Christianity, including the Gestalt of encultured African Christianity and its theology (Fiedler 1996/1997:165,180). An essential problem for the fight against HIV/AIDS, one could conclude, is not so much the difference between the Western Christian tradition and African culture $^{12}$, but rather a global economic structure, which immanently produces inequality, which according to Christian ethics is unjustifiable.

12 It seems to me that one has to differentiate between changes in the social fabric of "Western" societies, which is due to the structural change in the wake of modernisation/globalisation on the one hand, for example the acceptance of pre-marital sex due to the fact the marriage takes place later, often not before the late twenties, and on the other hand the ideological images which are propagated in commercial popular culture and the mass media, such as promiscuity connected with a hedonistic and materialistic culture. Empirical data show for example that most of the people live monogamous most of their lifetime. This distinction seems not always clear in Vorster (2003:345-361). 
The Christian churches and Christian theology thus have the task to incorporate a comprehensive social and theological analysis in their reflection on HIV/AIDS. Neither a merely activist approach nor an abstract deductive dogmatic approach will really help to address the problem of HIV/AIDS adequately theologically and practically. Rather, the problem of HIV/AIDS has to be placed in a more comprehensive framework, in which social changes can be seen in their relation to the process of globalisation. Then Christian (sexual) ethics can be developed which are faithful to Christian tradition as well as meaningful to the current context. I hope that my abovementioned argument provides some ideas for this endeavour. If this were successful, the church and theology would have indeed contributed for society en large. That would be a contribution to a truly public theology (Koopman 2003:3-19).

\section{Consulted literature}

Ackermann, D M 2002. “A Gendered Pandemic?” HIV/AIDS in South Africa: Problems and Possiblities for Feminist Ethics. Paper delivered at the Nordic Society of Theological Ethics, June 2002.

Baumann, G 2000. Liebe und Gewalt. Die Ehe als Metapher für das Verhaeltnis JHWH - Israel in den Prophetenbuechern. Stuttgart: Katholisches Bibelwerk (Stuttgarter Bibelstudien 185).

Benn, Chr 1997. Solidaritaet und Gemeinschaft. Die Studie und Erklaerung des Oekumenischen Rates der Kirchen zu HIV/AIDS. ÖR 46, 179-193.

-, 2002. The Influence of Cultural and Religious Frameworks on the Future Course of the HIV/AIDS Pandemic. JTSA 113, 3-18.

Botman, R 2002. Ethics and Socio-Political Transformation: Towards a Model of Partnerships in the Public Arena. Scriptura 72, 97-104.

Bundesministerium für Familie, Senioren, Frauen und Jugend (ed.) 2003. Die Familie im Spiegel der amtlichen Statistik. Lebensformen, Familienstrukturen, wirtschaftliche Situation der Familien und familiendemographische Entwicklung in Deutschland. Berlin: BMFSFJ (new expanded ed).

Carmody, B 2003. Religious Heritage and Premarital Sex in Zambia, JTSA 115, 79-90.

Chauke, E 2003. Theological Challenges and Ecclesiological Responses to Women Experiencing HIV/AIDS: A South Eastern Zimbabwe Context, in: Phiri et al. (eds): African Women, HIV/AIDS and Faith Communities. Pietermaritzburg: Cluster Publications, 128-148.

Denis, P 2003. Sexuality and AIDS in South Africa. JTSA 115, 63-77. 
De Villiers, E 2003. A Christian Ethics of Responsibility: Does it Provide an Adequate Theoretical Framework for Dealing with Issues of Public Morality? Scriptura 82, 23-38.

Dube, M 2003. Talitha Cum! Calling the Girl-Child and Women to Life in the HIV/AIDS and Globalization Era, in: Phiri, et al. (eds): African Women, HIV/AIDS and Faith Communities. Pietermaritzburg: Cluster Publications, 71-93.

Fiedler, K 1996/1997. Cook First, then Publish, in: Theology Cooked in an African Pot (ATISCA Bulletin Nos. 5/6, Special Volume), 165-180.

Haddad, B 2002. Gender Violence and HIV/AIDS: A Deadly Silence in the Church. JTSA 114, 93-116.

Hartlieb, E 1997. Die feministische Rede von der Suende. Grundstrukturen feministischer Argumentationen, in: Brandt, Sigrid et al. (eds). Suende. Ein unverstaendlich gewordenes Thema. Neukirchen-Vluyn: Neukirchener Verlag, 155-174.

-, 2000. Kann denn Liebe Suende sein? Zur sexuellen Obsession christlicher Suendenlehre, in: Keil, Siegfried \& Haspel M (eds). Gleichgeschlechtliche Lebensgemeinschaften in sozialethischer Perspektive. Neukirchen-Vluyn: Neukirchener Verlag, 99-121.

Haspel, M 1998. "Du sollst Deinen Vater und Deine Mutter ehren." Generationensolidarität in familialen Lebensformen der Spaetmoderne in sozialethischer Perspektive. epd-Dokumentation 38-39, H. 1, 33-43.

-, 2001. Art. "Sexualitaet, Sexualethik". Evangelisches Soziallexikon. Stuttgart: Kohlhammer, Sp. 1393-1402.

-, 2003a. Rechtfertigung, Versoehnung und Gerechtigkeit. Die Globalisierung als Herausforderung christlicher Soteriologie, ÖR 52, 472-490.

-, 2003b. Justification and Justice, in: Bloomquist, K \& Greive, W (eds): The Doctrine of Justification: Its Reception and Meaning Today (LWF Studies 02/2003). Geneva: LWF, 171-186.

-, 2003c. AIDS in Afrika! Eine Herausforderung für Kirche und Theologie in der Globalisierung. Deutsches Pfarrerblatt 103, 510-514.

-, 2004. Die Liebe Gottes und die Liebe der Menschen. Ehe, Lebensformen und Sexualitaet, in: Link-Wieczorek, U et al. Nach Gott im Leben fragen. Oekumenische Einfuehrung in das Christentum. Freiburg: Herder/ Guetersloh: Guetersloher Verlagshaus, forthcoming.

Hendriks, J 2002. AIDS in Sub-Saharan Africa: Between Denial and TruthTelling. Scriptura 81, 362-372.

Huber, W 1993. Toward an Ethics of Responsibility. Journal of Religion 73, No. 4, 573-592.

Kaesemann, E 1969³ ${ }^{3}$ Zur paulinischen Anthropologie, in: idem: Paulinische Perspektiven. Tuebingen: Mohr, 1993, 9-60. 
-, E 1980 ${ }^{4}$. An die Roemer Tuebingen: Mohr (Handbuch zum Neuen Testament $8 a$ ).

Kanyoro, M 2001. Der Katastrophe ins Auge sehen. EMS-Informationsbrief No. 4, 2-5.

Keil, S 1966. Absolutheit und Relativitaet der Normen in soziologischer und theologischer Sicht. NZSTh 8, 67-78.

-, 1997. Theologische Ueberlegungen zur Vielfalt der Geschlechterverhaeltnisse, in: Gestrich, Christof (ed.): Geschlechterverhaeltnis und Sexualitaet, 14-29 (Beiheft zur BThZ 14).

Keil S \& Haspel, M (eds) 2000. Gleichgeschlechtliche Lebensgemeinschaften in sozialethischer Perspektive. Beitraege zur rechtlichen Regelung pluraler Lebensformen. Neukirchen-Vluyn: Neukirchener Verlag.

Koopman, N 2003. Some Comments on Public Theology Today. JTSA 117, 319.

LenkaBula, P 2002. From the Womb into a Hostile World: Christian Ethics and Sexual Abuse against Children in South Africa. JTSA 114, 55-68.

Luther, Martin 1529. Ein Traubuechlein für die einfaeltigen Pfarrherrn, in: WA 30 III, 74-80 (= BSELK, 528-534).

Mwaungulu, $\mathrm{R}$ et al $2001^{2}$. The God of Love and Compassion. A Christian Meditation on AIDS. Zomba: Kachere/Balaka: Montfort Press.

Moodie, T. D \& Ndatshe, V 1994. Going for Gold. Men, Mines, and Migration. Berkeley/Los Angeles/London: University of California Press.

Moyo, F L 1998. The AIDS Crisis: A Challenge to the Integritiy of the Church in Malawi, in: Ross, Kenneth R. (ed.). Faith at the Frontiers of Knowledge. Blantyre: CLAIM/Bonn: Schirrmacher, 94-110.

Nave-Herz, R 1997. Familie heute. Wandel der Familienstrukturen und Folgen für die Erziehung. Darmstadt: WBG.

Nicolson, R 1996. God in Aids? A Theological Enquiry. London: SCM Press Ltd.

Nuernberger, K 2002. Theology of AIDS: A Lutheran/Moravian Case Study. Scriptura 81, 422-436.

Oekumenischer Rat der Kirchen (ed.) 1997. AIDS und die Kirchen. Eine Studie des Oekumenischen Rates der Kirchen. Frankfurt a.M: Lembeck, 45-51. (ORK).

Phiri, I A 2002. "Why Does God Allow Our Husbands to Hurt Us?" Overcoming Violence against Women. JTSA 114, 19-30.

Qakisa, M 2002. Let's Talk about Sex: Reaching Young People through the Media in the Age of AIDS. JTSA 114, 79-92.

Schrage, W 1989 ${ }^{5}$. Ethik des Neuen Testaments. Goettingen: Vandenhoeck \& Ruprecht, (NTD Ergaenzungsreihe: Grundrisse zum NT 4). 
Sielert, U 1993². Sexualpaedagogik. Konzeptionen und didaktische Anregungen. Weinheim: Beltz.

Vorster, J M 2003. HIV/AIDS and Human Rights. The Ecumenical Review 55(4), 345-361.

Weinreich, S \& Benn, C 2003. AIDS. Eine Krankheit veraendert die Welt. Daten - Fakten - Hintergruende, (ed. by Brot fuer die Welt, DIFAEM, eed, EMW). Frankfurt a.M: Lembeck.

West, G 2003. Reading the Bible in the Light of HIV/AIDS in South Africa. The Ecumenical Review 55(4), 335-344. 